\title{
Gerakan Ayo Kuliah Dengan KIP Kuliah Untuk Memotivasi Pelajar MA Al-Furqon Pasuruan
}

\author{
Yuniar Mujiwati', Muchammad Choiron², Febila Nusantara Prasetia ${ }^{3}$, Elok Fauziah4, Nabila Enggal \\ Genanta $^{5}$ \\ 1,4,5Program Studi PPKn, Fakultas Pedagogi dan Psikologi, Universitas PGRI Wiranegara Pasuruan \\ 2,3Program Studi Matematika, Fakultas Pedagogi dan Psikologi, Universitas PGRI Wiranegara Pasuruan \\ *e-mail: yuniar.caliptra@gmail.com ${ }^{1}{ }_{2}$ choironjanuzaj@gmail.com $^{2}{ }_{2}$ febilanp@ gmail.com $^{3}$, \\ elokfauziah2303@gmail.com ${ }^{4}$, nabilaenggal8@gmail.com ${ }^{5}$
}

Nomor Handphone Untuk keperluan koordinasi : 0894-3970-85961

\begin{abstract}
Abstrak
Permasalahan yang di angkat di dalam jurnal ini yakni mengenai bagaimana memotivasi pelajar SMA untuk melanjutkan pendidikan ke perguruan tinggi. Sasaran pengabdian KKN kami yaitu 8 siswa kelas XII dan 5 dewan guru di MA Al Furqon Pasuruan. Setelah kami melakukan wawancara ke beberapa siswa dan guru, kami menemukan permasalahan yaitu siswa MA Al Furqon tidak ingin melanjutkan pendidikan setelah SMA. Kebanyakan siswa ingin langsung melanjutkan kerja dan hanya menjadi ibu rumah tangga saja. Hal itu dikarenakan mereka tidak ada keinginan melanjutkan ke perguruan tinggi dan berasal dari keluarga berekonomi rendah. Maka Tim KKN Universitas PGRI Wiranegara melakukan kegiatan Sosialisasi Gerakan Ayo Kuliah dengan beberapa materi antara lain : Penjelasan KIP Kuliah, Pentingnya Pendidikan Tinggi untuk Masa Depan, Program Kemendikbud untuk Mahasiswa, Mengenalkan Kampus Uniwara, dan Kerja Bakti Lingkungan Sekolah. Peserta sosialisasi terlihat sangat antusias mengikuti sosialisasi Tim KKN, terlihat dari aktifnya kegiatan tanya jawab Tim KKN dan siswa serta guru dalam sosialisasi tersebut.
\end{abstract}

Kata kunci: Mahasiswa, Pelajar, Pendidikan, Sosialisasi

The problem raised in this journal is how to motivate high school students to continue their education to college. The targets of our KKN service are 8 grade XII students and 5 teacher councils at MA Al Furqon Pasuruan. After we conducted interviews with several students and teachers, we found a problem, namely MA Al Furqon students did not want to continue their education after high school. Most students want to go straight to work and only become housewives. This is because they have no desire to continue to college and come from low-income families. So the KKN Team of PGRI Wiranegara University carried out the Socialization of the Let's Lecture Movement with several materials including: Explanation of KIP Lectures, The Importance of Higher Education for the Future, Kemendikbud Programs for College Students, Introducing the Uniwara Campus, and Clean the School's Environment. The socialization participants seemed very enthusiastic about participating in the socialization of the Community Service Team, as seen from the active question and answer activities of the KKN Team and students and teachers in the socialization.

Keywords: College Student, Student, Education, Socialization

\section{PENDAHULUAN}

Pendidikan adalah usaha sadar untuk menumbuhkembangkan potensi sumber daya manusia. Sebab pendidikan merupakan wahana atau salah satu instrumen yang di gunakan bukan saja untuk membebaskan manusia dari keterbelakangan melainkan juga dari kebodohan dan kemiskinan. Pendidikan diyakini mampu menanamkan kapasitas baru bagi semua orang untuk mempelajari pengetahuan dan keterampilan baru sehingga dapat diperoleh manusia produktif [1]. Dengan kemampuan inilah manusia terus membuat perubahan untuk mengembangkan hidup dan kehidupan dirinya sebagai manusia. Pemerintah secara terus menerus berusaha semaksimal mungkin untuk meningkatkan kualitas pendidikan indonesia, dengan upaya sedemikian rupa yang bertujuan agar pendidikan indonesia ini terlihat lebih baik, karena pendidikan Nasional ini ingin menciptakan manusia yang semakin cerdas, terampil, berbudi pekerti yang luhur serta bertakwa kepada Tuhan Yang Maha Esa. Hal ini ditegaskan dalam Pendidikan Nasional Indonesia yaitu : "Pendidikan berdasarkan pancasila dan undang- 
undang dasar negara republik indonesia tahun 1945 yang berakar pada nilai-nilai agama, kebudayaan nasional indonesia dan tanggap terhadap tuntutan perubahab zaman"(UU RI no 20 tahun 2003). Berarti pendidikan juga memberi pedoman yang kuat bagi perjalanan hidup manusia. Dapat di artikan bahwa pendidikan juga memberikan nilai keindahan. Perguruan tinggi adalah suatu lembaga pendidikan yang menyelanggarakan pendidikan dan berbagai macam keahlian, misalnya: bidang pendidikan, ekonomi, hukum, psikologi, teknik, kesehatan dan lainlain sesuai dengan Undang-Undang no 20 tahun 2003 menetapkan perguruan tinggi berupa akademik, politeknik, sekolah tinggi, institut atau universitas yang ditetapkan oleh pemerintah. Menjejangkan karir di perguruan tinggi akan mematangkan siswa baikdidalam memperoleh ilmu, berperilaku dan cara berfikir. Cara berfikir yang rasional syarat akan pengujian ilmiah, serta mampu dipertanggung jawabkan kebenarannya, merupakan ciri khas yang dimiliki oleh mahasiswa. Mahasiswa selalu menggunakan fikirannya secara rasional jika memecahkan suatu masalah. Sedangkan matangnya suatu ilmu yang ditempuh mahasiswa diperguruan tinggi, akan menjadikkan mahasiswa 4 berperilaku baik pula.[2]

Pada saat ini tidak hanya siswa saja yang giat mencari perguruan tinggi untuk melanjutkan studinya, tetapi banyak perguruan tinggi memperbaiki citranya, baik dari insfratruktur maupun organisasinya guna untuk memikat siswa agar tertarik untuk melanjutkan studinya. Melanjutkan ke perguruan tinggi diawali dari adanya rasa ketertarikan dan kebutuhan untuk mengembangkan ilmu pengetahuan. Adanya minat dalam diri individu akan mendorong seseorang untuk melakukan suatu tindakan dan partisipasi didalamnya. Begitu juga dengan minat siswa melanjutkan studi ke perguruan tinggi akan mendorong mereka untuk berusaha memasuki perguruan tinggi karena mereka ingin mengembangkan ilmu dan pengetahuan. Minat dapat dilihat dari sikap seseorang yang mulai menaruh perhatian pada suatu hal yang menjadi keinginan dan kegemarannya. Individu yang memiliki minat terhadap suatu hal secara otomatis akan melakukan suatu tindakan dan usaha untuk dapat mencapai hal yang diinginkannya. Kebutuhan akan pendidikan tinggi saat ini terus menerus meningkat seiring demi tercapainya tujuan pembangunan nasional dan persaingan global. Sedangkan Mereka memilih perguruan tinggi sebagai tempat yang terakhir untuk meneruskan karirnya didalam memperoleh pendidikan yang berarti bagi dirinya [3]. Untuk mendapatkan prestasi belajar yang baik siswa melakukan proses melalui usaha belajar. Prestasi belajar juga merupakan kemampuan yang di peroleh setiap anak atau siswa setelah kegiatan belajar. Kegiatan belajar yang optimal akan mempengaruhi tingkat keberhasilan pada prestasi 5 siswa dalam belajar. Belajar ialah suatu proses usaha yang dilakukan seseorang untuk memperoleh suatu perubahan tingkah laku yang baru secara keseluruhan, sebagai hasil pengalamannya sendiri [4]. Hasil belajar yang diperoleh siswa diukur berdasarkan perbedaan tingkah laku sebelum dan sesudah belajar dilakukan. Salah satu indikator terjadi perubahan dalam diri siswa sebagai hasil belajar di sekolah dapat dilihat melalui nilai yang diperoleh siswa pada akhir semester untuk mengetahui prestasi belajar siswa.

MA Al-Furqon setiap tahun siswanya telah lulus 100\% dan di lingkungan sekitar banyak dijumpai adanya siswa yang kurang berminat melanjutkan ke jenjang yang lebih tinggi sedangkan siswa tersebut memiliki prestasi yang tinggi. Hal tersebut di karenakan siswa itu sendiri beranggapan bahwa melanjutkan studi ke jenjang yang lebih tinggi tidak menjamin masa depannya lebih baik. Ada juga yang minatnya tinggi untuk melanjutkan ke jenjang yang lebih tinggi, tetapi siswa tersebut memiliki prestasi yang kurang, penyebabnya siswa dalam belajarnya sangat kurang. Prestasi belajar dikatakan memuaskan apabila memenuhi aspek yakni kognitif, afektif, dan psikomotorik [5]. Sebaliknya dikatakan prestasi kurang memuaskan jika seseorang belum mampu memenuhi target dalam ketiga kriteria tersebut. Maka prestasi belajar merupakan tingkat kemanusiaan yang dimiliki siswa dalam menerima, menolak, dan menilai informasi- informasi yang diperoleh dalam proses belajar mengajar. Peneliti memilih siswa pada MA Al-Furqon karena merupakan sekolah yang tergolong baik. Namun sampai sekarang ini masih sedikit sekali siswa yang melanjutkan studi ke perguruan tinggi. Karena ini merupakan sekolah baik maka muncul banyak pertanyaan apa yang menyebabkan siswa yang melanjutkan studi ke perguruan tinggi sangat sedikit. Dalam kasus ini siswa kelas XII MA Al-Furqon haruslah menyesuaikan diri dengan prestasi belajar sehingga meningkatkan minat untuk melanjutkan 
keperguruan tinggi dan motivasi belajar yang baik sebagai dasar dalam meningkatkan minat dalam melanjutkan studi ke perguruan tinggi.

\section{METODE}

Kami melakukan kegiatan KKN di MA Al Furqon Pasuruan dengan Gerakan Ayo Kuliah dengan sasaran siswa kelas XII dan dewan guru. KKN ini bertujuan memberikan akses informasi perguruan tinggi ke peserta didik. Adapun point kegiatan KKN yang kami lakukan antara lain :

\section{Sosialisasi KIP Kuliah Merdeka}

Sosialisasi ini dilakukan pada hari Jum'at, 23 Juli 2021 secara tatap muka di MA Al Furqon dengan diikuti oleh 8 siswa kelas XII dan 5 dewan guru MA Al Furqon Pasuruan. Menjelaskan tentang program dari pemerintah yaitu KIP dan KIP Kuliah. Sosialisasi ini yaitu bertujuan untuk menjelaskan pengertian KIP, cara mendaftar dan memperoleh KIP, berkas yang harus disiapkan untuk mendaftar KIP, serta menjelaskan manfaat yang bisa didapatkan dengan adanya program KIP-Kuliah kepada dewan guru dan siswa, dengan harapan agar memudahkan siswa dalam memiliki fasilitas pendidikan yang layak serta tercapainya Sumber Daya Manusia (SDM) yang berintelektual dan berkualitas. Sosialisasi ini dapat dikatakan berhasil, yaitu apabila siswa sudah memahami dan dapat mempraktekan langkah- langkah dalam melakukan pendaftaran program KIP Kuliah Merdeka sampai tahap pendaftaran ke Perguruan Tinggi.

\section{Sosialisasi Pentingnya Pendidikan Tinggi Untuk Masa Depan}

Sosialisasi ini dilakukan pada hari Senin, 26 Juli 2021 secara daring melalui aplikasi Google Meet dengan diikuti oleh 15 siswa kelas XII MA Al Furqon Pasuruan. Sosialisasi ini menjelaskan bahwa pentingnya pendidikan tinggi untuk masa depan, karena dengan memiliki pendidikan yang tinggi dapat mempersiapkan diri sendiri untuk memasuki dunia kerja yang pada era ini harus minimal berijazah S- 1 serta dengan mengenyam pendidikan tinggi kita bisa memiliki pengetahuan dan keterampilan yang matang sehingga dapat meniti karirnya dengan baik. Indikator kebersihan dari sosialisasi ini yaitu apabila siswa sudah bisa merubah mindset atau pola pikirnya ke arah yang lebih baik dan menimbulkan semangat optimisme untuk dapat melanjutkan ke pendidikan Perguruan Tinggi.

\section{Sosialisasi Program Kemendikbud Untuk Mahasiswa}

Sosialisasi ini dilakukan pada hari Senin, 26 Juli 2021 secara daring melalui aplikasi Google Meet dengan diikuti oleh 15 siswa kelas XII MA Al Furqon Pasuruan. Menjelaskan beberapa program dari kemendikbud untuk mahasiswa, dan apa saja manfaat yang akan diperoleh. Untuk saat ini banyak sekali program dari kemendikbud yang dapat memberikan pengalaman dan pengetahuan lebih yang bisa didapatkan oleh mahasiswa seperti program kampus mengajar, pertukaran mahasiswa, magang bersertifikat, dan studi independent yang tentunya dapat menambah pengalaman dalam dunia pendidikan dan dunia kerja, serta mendapat benefit berupa uang saku dan konversi SKS. Hal tersebut sangat menarik sekali jika dijelaskan kepala siswa yang mungkin akan membuat siswa menjadi lebih tertarik untuk melanjutkan ke jenjang studi lanjut.

\section{Mengenalkan Kampus Uniwara}

Sosialisasi ini dilakukan pada hari Senin, 26 Juli 2021 secara daring melalui aplikasi Google Meet dengan diikuti oleh 15 siswa kelas XII MA Al Furqon Pasuruan. Sosialisasi ini menjelaskan menjelaskan mengenai alur pendaftaran masuk Uniwara dan juga proses pendaftaran dengan menggunakan KIP. Mendaftar menggunakan KIP hanya membayar Rp 250.000 dan $\mathrm{Rp} 175.000$ di awal pendaftaran dan langaung bisa kuliah S-1 serta mendapat benefit yaitu uang saku per bulan yang dapat dikapai mahasiswa untuk keperluan selama proses kuliah. Sosialisasi ini juga menjelaskan fakultas dan program studi apa saja yang ada di Uniwara serta menjelaskan keseruan saat kuliah di Uniwara. Indikator kebersihan sosialisasi ini yaitu siswa dapat memahami alur pendaftaran kuliah dan juga mengetahui apa saja yang ada di UNIWARA. 


\section{HASIL DAN PEMBAHASAN}

Kami melakukan wawancara ke 5 dari 8 siswa kelas XII untuk menemukan alasan-alasan mengapa kebanyakan siswa MA Al Furqon Pasuruan tidak melanjutkan ke perguruan tinggi, antara lain :

Siswa $1 \quad$ : Saya berasal dari keluarga kurang mampu

Siswa $2 \quad$ : Tradisi turun menurun keluarga, setelah lulus SMA langsung bekerja

Siswa 3 : Saya ingin langsung mencari uang sendiri

Siswa $4 \quad$ : Tidak ada info dari sekolah

Siswa 5 : Malas belajar lagi

Kami melakukan kegiatan KKN pada tanggal 23, 26, dan 31 Juli 2021 di MA Al Furqon Pasuruan. Adapun kegiatan KKN yang kami lakukan, sebagai berikut :

\section{Sosialisasi KIP Kuliah Merdeka}

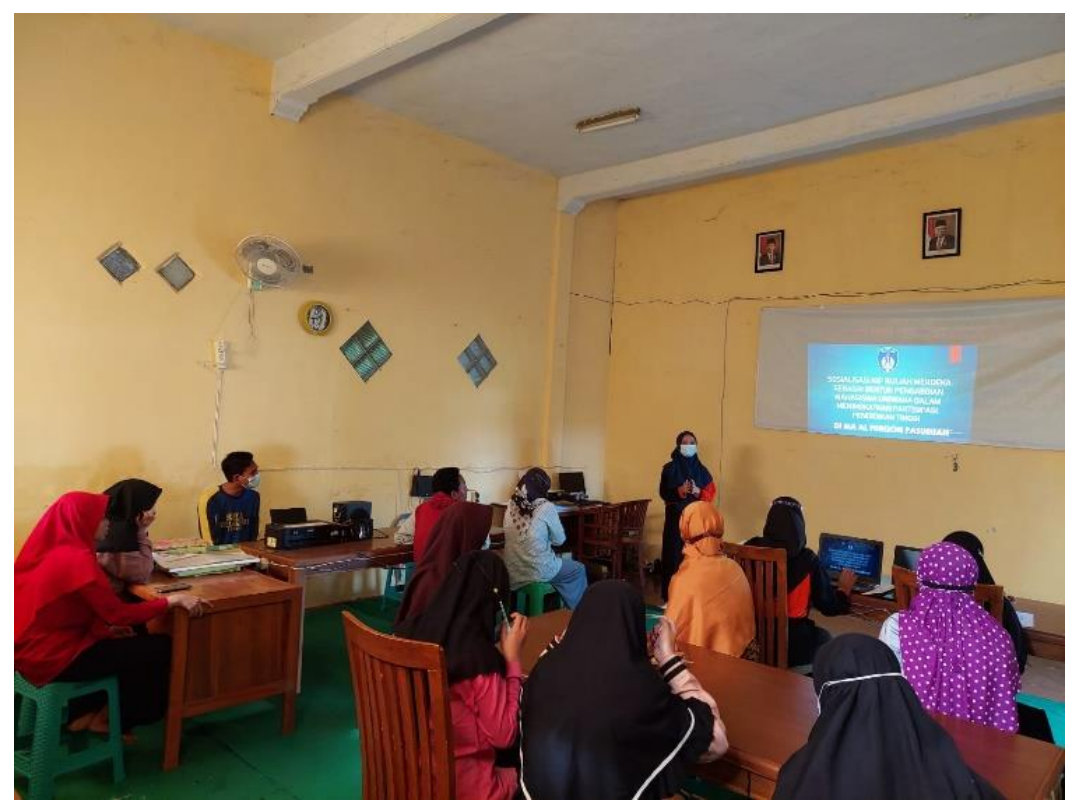

Gambar 1. Sosialisasi KIP Kuliah Merdeka

Tim KKN menjelaskan pengertian KIP kepada peserta sosialisasi bahwa menurut Kemendikbud, Kartu Indonesia Pintar Kuliah (KIP-Kuliah) adalah bantuan berupa uang tunai, perluasan akses, dan kesempatan belajar dari pemerintah dalam membantu siswa yang terkendala keterbatasan ekonomi terutama yang berprestasi untuk dapat melanjutkan studi kejenjang perguruan tinggi. Dengan adanya KIP, pelajar berekonomi rendah tidak perlu ragu untuk melanjutkan pendidikan ke perguruan tinggi. Ada beberapa manfaat yang didapatkan dari KIP-Kuliah ini, yaitu 1) Pembebasan biaya pendaftaran perguruan tinggi; 2) Pembebasan biaya kuliah; 3) Bantuan biaya hidup bulanan. Persyaratan penerima KIP-Kuliah yaitu: 1) Siswa SMA Sederajat yang akan lulus pada tahun berjalan; 2) Memiliki potensi akademik namun keterbatasan ekonomi yang dibuktikan dengan : a) Mempunyai KIP; b) Berasal dari Program Keluarga Harapan (PKH); c) Pemegang Kartu Keluarga Sejahtera (KKS); d) Mahasiswa dari panti sosial/panti asuhan; e) Masuk dalam kategori 4 pada Data Terpadu Kesejahteraan Sosial (DTKS); 3) Lulus seleksi melalui semua jalur masuk Perguruan Tinggi.

Sebelum melakukan registrasi akun KIP-Kuliah ada beberapa berkas yang perlu disiapkan, antara lain : 1) Nomor Induk Kependudukan (NIK); 2) Nomor Induk Siswa Nasional (NISN); 3) Nomor Pokok Sekolah Nasional (NPSN); 4) Email yang masih aktif. Alur pendaftaran KIP-Kuliah sebagai berikut; 1) Registrasi akun melalui laman kip-kuliah.kemdikbud.go.id atau download KIP Kuliah mobile apps; 2) Mengisi form NIK, NISN, NPSN dan email; 3) Validasi NIK, NISN dan NPSN; 4) Mendapatkan nomor pendaftaran dan kode akses; 5) menyelesaikan proses registrasi; 6) Mendaftar dan mengikuti seleksi Perguruan Tinggi; 7) Verivikasi oleh Perguruan Tinggi. 


\section{Sosialisasi Pentingnya Pendidikan Tinggi Untuk Masa Depan}

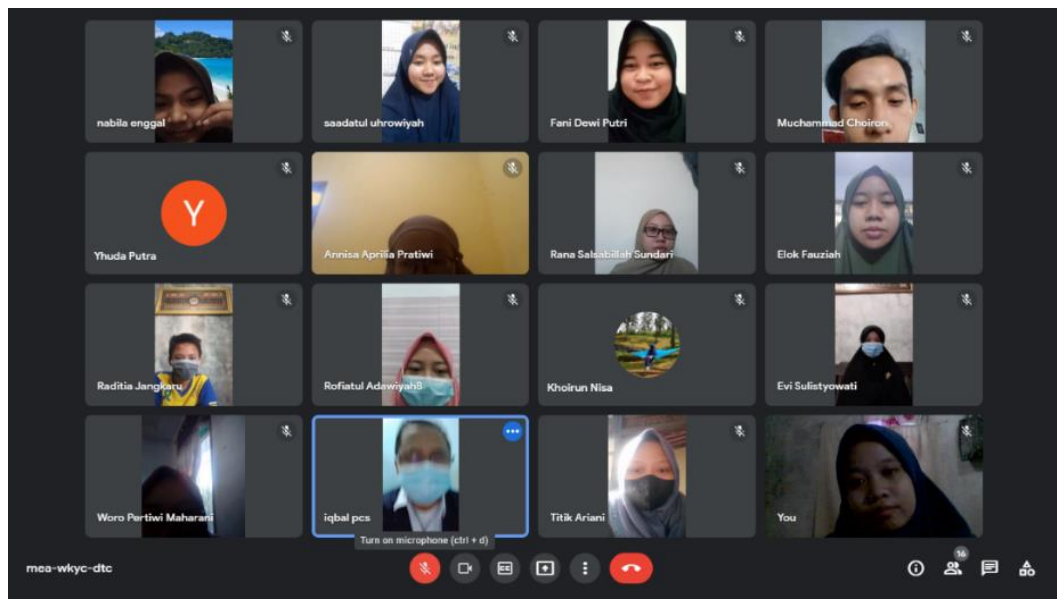

Gambar 2. Sosialisasi Pentingnya Pendidikan Tinggi

Pendidikan Tinggi adalah jenjang pendidikan setelah pendidikan menengah yang mencakup program diploma, program sarjana, program magister, program doktor, dan program profesi, serta program spesialis, yang diselenggarakan oleh perguruan tinggi berdasarkan kebudayaan bangsa Indonesia. Adapun fungsi seseorang melanjutkan ke pendidikan tinggi antara lain : mengembangkan kemampuan dan membentuk watak serta peradaban bangsa yang bermartabat dalam rangka mencerdaskan kehidupan bangsa; mengembangkan Sivitas Akademika yang inovatif, responsif, kreatif, terampil, berdaya saing, dan kooperatif melalui pelaksanaan Tridharma; mengembangkan Ilmu Pengetahuan dan Teknologi dengan memperhatikan dan menerapkan nilai Humaniora. Bagaimanapun juga mahasiswa merupakan menjadi tulang punggung negara dan melanjutkan estafet kepemimpinan di masa-masa mendatang. Artinya seperti apa nantinya sebuah Negara tidak bisa lepas dari kreativitas pemikiran para mahasiswa. Kelompok mahasiswa dalam kehidupan sosial mendapatkan stratifikasi tempat dan peran yang teramat penting sebagai kelompok pemikir elit. Kepada merekalah sebenarnya masa depan suatu bangsa amat ditentukan apakah bergulir menuju kemunduran ataukah menuju kecerahan. Hal tersebut karena mahasiswa memiliki berbagai fungsi strategis sebagai agent of change, transfer of knowledge, transfer of ideology, indicator of national or political stability, agent of globalization, dan human transformer. Sebuah survey yang dilakukan di Yogyakarta terhadap 200 mahasiswa sekitar bulan Mei 2004 yang menemukan bahwa sekitar $70 \%$ mahasiswa masih yakin bahwa mereka adalah kekuatan akan perubahan (agent of change). Oleh karena itu peran yang penting inilah yang seharusnya menjadi tuntutan pada mahasiswa untuk mengoptimalkan kompetensi pada dirinya.

Hal ini semakin penting bila dikaitkan dengan pengajaran di lembaga pendidikan tinggi yang tentunya harus mengedepankan output dan outcome yang memiliki kompetensi yang diharapkan sesuai dengan disiplin ilmunya. Artinya perguruan tinggi tidak hanya menghasilkan produk lulusan yang kompeten, namun mampu diserap oleh masyarakat pengguna lulusan, baik dalam tataran organisasi birokrasi pemerintahan, sipil atau militer, perusahaan swasta ataupun negeri, maupun organisasi kemasyarakatan yang lain. Apalagi terjangan globalisasi membuat situasi menjadi semakin kompetitif dan global, sehingga pendidikan tinggi dianggap menjadi sarang untuk meningkatkan syarat kompetensi bagi seseorang. Ditambah lagi keberadaan seseorang yang tidak lagi terbatas pada satu negara saja, tetapi melintas ke beberapa negara lain, maka membutuhkan kompetensi yang semakin detail dan kompleks.Oleh karena kondisi seperti di atas perlu mendapatkan respon dari para siswa untuk segera membuat pilihan pada Perguruan Tinggi. Memang pilihan untuk melanjutkan ke pendidikan tinggi bukanlah satusatunya jawaban bagi siswa untuk mengembangkan dirinya, ada berbagai pilihan lain misalnya langsung mencari kerja. Namun demikian perlu disadari bahwa peningkatan penggangguran pada pendidikan menengah atas lebih banyak prosentasenya daripada mereka yang lulus dari 
perguruan tinggi. Berdasarkan review dari BPS tahun 2005 ada sekitar 3.911.502 lulusan SLTA yang menganggur dibandingkan lulusan perguruan tinggi yang hanya 385.418. Hal ini menunjukan bahwa pangsa pasar masih menganggap bahwa Perguruan Tinggi menjadi prasyarat utama untuk menerima calon karyawan mereka.

Namun demikian memilih perguruan tinggi harus dilakukan dengan penuh kehatihatian, karena ada berbagai criteria sebuah Perguruan Tinggi berkualitas atau tidak. Banyak siswa mengadu nasib untuk meraih tempat di PTN, padahal patut disadari bahwa kapasitas PTN hanya bisa menampung 5\% dari ribuan pelamar tes masuk PTN. Selain itu dengan adanya peraturan pemerintah tentang akreditasi, maka istilah PTN dan PTS menjadi sangat tidak signifikan untuk diperbandingkan. Hal tsb karena hasil akreditasi yang menentukan kualitas dan kompetensi lulusan Perguruan Tinggi bukan nama besar atau status swasta / negeri. Selain itu perlu juga untuk memperhatikan sustainability dari sebuah Perguruan Tinggi, yang dapat dilihat dari sarana / prasarana yang dimiliki, jenjang pendidikan dan kemampuan akademik staf pengajar dan disiplin dalam proses belajar mengajar. Jangan tergiur hanya dengan harga murah dan kelulusan kilat, karena nantinya tidak akan memberikan dampak positif yang signifikan pada peningkatan kompetensi seseorang.

\section{Sosialisasi Program Kemendikbud Untuk Mahasiswa}

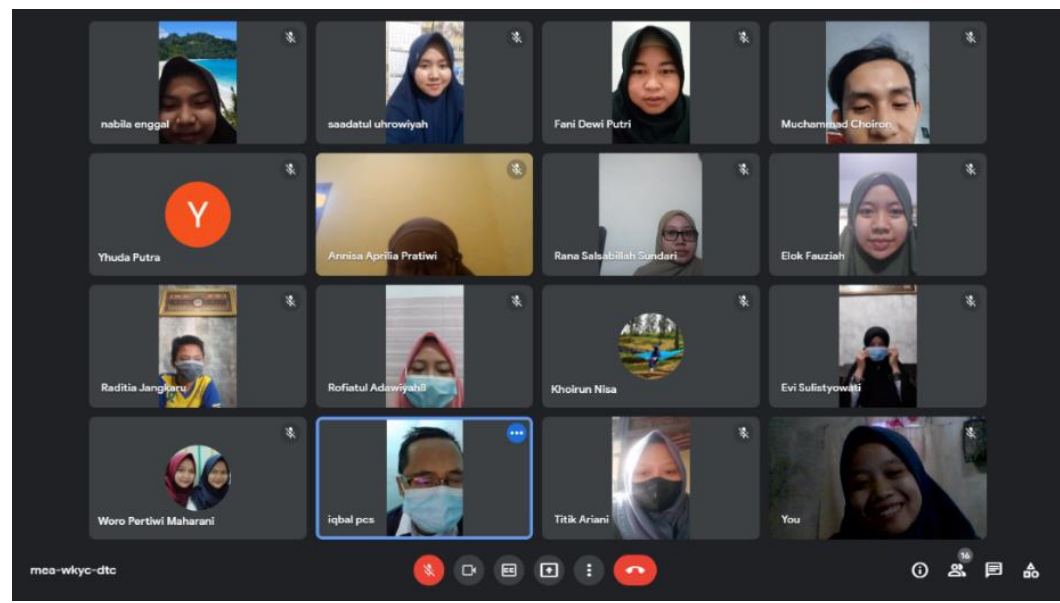

Gambar 3. Sosialisasi Program Kemendikbud Untuk Mahasiswa

Tim KKN menjelaskan program Kemendikbud yaitu Merdeka Belajar adalah memberi kebebasan dan otonomi kepada lembaga pendidikan, dan merdeka dari birokratisasi, dosen dibebaskan dari birokrasi vang berbelit serta mahasiswa diberikan kebebasan untuk memilih bidang yang mereka sukai. Kampus Merdeka merupakan kebijakan Menteri Pendidikan dan Kebudayaan, yang bertujuan mendorong mahasiswa untuk menguasai berbagai keilmuan yang berguna untuk memasuki dunia kerja. Kampus Merdeka memberikan kesempatan bagi mahasiswa untuk memilih mata kuliah yang akan mereka ambil. Adanya konsep belajar merdeka tentunya bertujuan untuk memberikan keleluasaan kepada mahasiswa untuk belajar diluar kampus. Konsep tersebut terus dikembangkangkan oleh Kemendikbud sebagai upaya untuk mendapatkan calon pemimpin masa depan yang berkualitas. Ada empat program Kampus Merdeka yang didukung LPDP di tahun 2021, yaitu Kampus Mengajar, Magang dan Studi Independen Bersertifikat (microcredentials), Indonesian International Student Mobility Awards (IISMA), serta Pertukaran Mahasiswa Merdeka.

Dalam Kampus Mengajar, Kemendikbud mengajak mahasiswa untuk menjadi agen perubahan pendidikan dengan mengajar di berbagai SMP terpilih. Mahasiswa membantu pembelajaran literasi dan numerasi untuk pelajar SMP selama satu semester dengan tujuan peningkatan skor Programme for International Student Assessment (PISA). Kriteria penerima antara lain Mahasiswa berasal dari universitas dan prodi dengan akreditasi minimal B, IPK mahasiswa minimal 3.0, Mahasiswa memiliki pengalaman mengajar atau berorganisasi. Bantuan 
pendanaan yang didapat antara lain Bantuan potongan UKT, Bantuan biaya hidup, dan akomodasi Biaya transportasi ke sekolah tujuan.

Sedangkan untuk Magang dan Studi Independen Bersertifikat (microcredentials), biaya hidup dan jaminan SKS diberikan untuk mahasiswa yang berhasil diterima magang di program dan organisasi kelas dunia yang diakui Kemendikbud selama 1 sampai 2 semester penuh. Mahasiswa akan terlibat dalam pemecahan masalah/isu nyata, mendapat bimbingan secara full time, serta imersif dan disertai sertifikat industri. "Uang saku dan biaya hidup selama magang disubsidi oleh Kemendikbud," jelas Kemendikbud. Cakupan Magang Bersertifikat antara lain Mahasiswa magang di perusahaan yang diakui Kemendikbud selama 1-2 semester penuh, Uang saku dan biaya hidup selama magang disubsidi oleh Kemendikbud, Mahasiswa menerima sertifikat kompetensi dari perusahaan setelah selesai magang. Sedangkan Cakupan Studi Independen Bersertifikat antara lain Mahasiswa mengikuti program sertifikasi atau short course yang diakui Kemendikbud selama 1 sampai 2 semester penuh, Biaya partisipasi dan biaya hidup selama studi independen disubsidi oleh Kemendikbud, Mahasiswa menerima sertifikat jika lulus program sertifikasi atau short course.

Beasiswa mobilitas internasional Indonesian International Student Mobility Awards (IISMA) diberikan kepada mahasiswa S1 yang belajar 1 sampai 2 semester di perguruan tinggi luar negeri terpilih. Mahasiswa dapat memilih beberapa jenis kegiatan, seperti student exchanges selama satu semester yang berjumlah 10 hingga 20 SKS, visiting student programme selama satu semester yang berjumlah 10 hingga 20 SKS, atau short courses di bawah 1 semester dengan jumlah SKS variatif. Dukungan dari Kemendikbud \& LPDP: Konversi/ penyetaraan SKS dari universitas luar negeri, Pendanaan untuk mengikuti program melalui beasiswa, Persiapan khusus untuk program mobilitas internasional, Layanan akademik dan non-akademik.

Program lainnya dari Kampus Merdeka yang didukung LPDP yakni Pertukaran Mahasiswa Merdeka. Program ini memberikan beasiswa untuk mahasiswa yang melakukan pertukaran ke perguruan tinggi lain di dalam negeri selama satu semester. Tujuannya adalah untuk saling mengenal antara satu daerah dengan daerah lainnya guna mempelajari keragaman kebudayaan Indonesia serta mendorong penguatan dan perluasan kompetensi akademik mahasiswa. Kriteria penerima manfaat: Mahasiswa berasal dari PTN/ PTS dan prodi yang terakreditasi, Mahasiswa semester 3 sampai 8, Mahasiswa memiliki IPK minimal 2.75. Bantuan pendanaan: Bantuan potongan UKT, Bantuan biaya hidup dan akomodasi, Biaya transportasi ke dan dari PT tujuan, Bantuan asuransi kesehatan (BPJS).

Dengan adanya sosialisasi Program Kemendikbud ini, diharapkan dapat memotivasi pelajar MA Al-Furqon untuk bisa melanjutkan pendidikan ke perguruan tinggi. Karena program kemendikbud ini bisa dijadikan untuk menambah pengalaman siswa ketika sudah menjadi mahasiswa sebelum memasuki dunia kerja.

\section{Mengenalkan Kampus Uniwara}

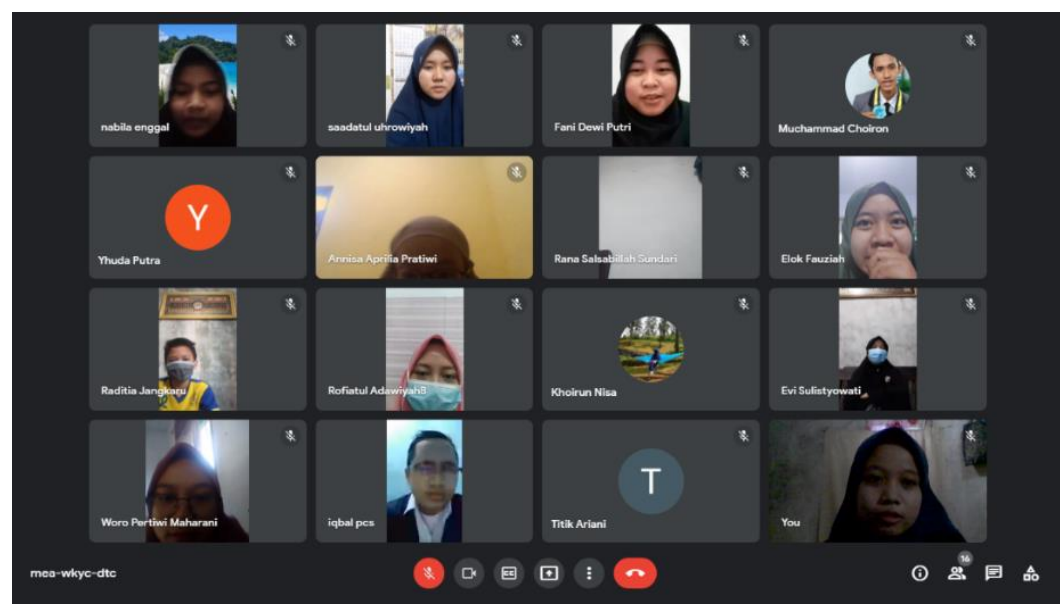

Gambar 4. Mengenalkan Kampus Uniwara 
Banyak perguruan tinggi yang memberikan kemudahan akses yaitu gratis masuk perguruan tinggi bagi mahasiswa baru yang memiliki KIP, begitu pula dengan Kampus kebanggaan kami yaitu Universitas PGRI Wiranegara Pasuruan. Kampus Uniwara memberikan kemudahan akses berupa gratis biaya kuliah sampai mendapatkan gelar S-1 hanya dengan memiliki kartu KIP Kuliah. Alur pendaftarannya pun sangat mudah, antara lain:

- Biaya Pendaftaran : melakukan pembayaran pandaftaran melalui rekening PPLPP PGRI Pasuruan sebesar Rp. 250.000,-

- Formulir Pendaftaran : sebelum mahasiswa melakukan pembayaran pendaftaran, mahasiswa dapat menyerahkan beberapa persyaratan seperti ijazah lulusan SMA/SMK, Foto asli KTP dan KK, Foto diri resmi 4 × 6 (digital) setelah itu mahasiswa melakukan pembayaran pendaftaran dan mengisi formulir pendaftaran online (bit.ly/PMBUNIWARA2021).

- Tes Potensi Akademik : mahasiswa dapat mengikuti tes potensi akademik online (bit.ly/TPAUNIWARA2021).

- Verifikasi dan Registrasi : cek status pendaftaran dan membayar biaya masuk / registrasi di Front Office UNIWARA.

- Biaya Pendidikan : mahasiswa menerima info biaya pendidikan yang harus dibayarkan, membayar minimal Rp. 175.000 di awal pendaftaran sebagai tanda kesungguhan mendaftar.

- Jadwal Masuk : mahasiswa menunggu jadwal masuk kuliah (sekitar agustus)

Kampus Uniwara tidak hanya memberikan kemudahan akses gratis kuliah saja, tetapi juga menawarkan fakultas dan program studi yang sudah berakreditasi B yaitu Fakultas Pedagogi dan Psikologi yang terdiri dari Program Studi S-1 Pendidikan Pancasila dan Kewarganegaraan, S-1 Pendidikan Matematika, S-1 Pendidikan Ekonomi, S-1 Pendidikan Bahasa dan Sastra Indonesia, dan S-1 Pendidikan Bahasa Inggris. Adapun Fakultas yang baru saja berdiri yaitu Fakultas Teknologi dan Sains yaitu Program Studi S-1 Ilmu Komputer, S-1 Teknik Industri, dan S-1 Teknologi Pangan. Kampus Uniwara juga menawarkan Program Pascasarjana yaitu S-2 Magister Pendidikan Ekonomi.

Program Studi diatas tadi pastinya sudah terakreditasi baik. Dosen-dosen sudah S-2 dan S-3 sehingga ahli di bidangnya dan yang pasti super humble dengan mahasiswa. Menjadi mahasiswa di kampus Uniwara tidak hanya diberi pelajaran kuliah saja, tetapi juga diajarkan untuk berorganisasi. Ada banyak organisasi disana yaitu HMPS (HMPS Matematika, HMPS Bahasa Inggris, HMPS Ekonomi, HMPS PPKN, HMPS Bahasa Indonesia) dan Ormawa (Soul Voice, Ukmor, UKM Tari, Teater Manunggal, UKM Mapaladewa, UKM LRM, dan lain-lain). Sehingga mahasiswa tidak hanya memiliki soft skill saja (pembelajaran di dalam kelas), tetapi juga memiliki hard skill (dari organisasi yang diikuti).

Banyak dari pelajar di MA Al Furqon menyayangkan jika kuliah tidak bisa disambi kerja. Tetapi karena Kampus Uniwara dekat dengan rumah, kuliah disana bisa juga disambi kerja. Kuliah pagi dan kerja sore, kebanyakan mahasiswa di Uniwara menerapkan hal itu. Jadi tidak ada alasan lagi untuk tidak kuliah di Uniwara karena ada banyak manfaat yang bisa diambil.

\section{Kerja Bakti Lingkungan Sekolah}

Hari terakhir KKN kami yaitu pada hari Sabtu, 31 Juli 2021, kami melakukan kerja bakti lingkungan sekolah MA Al Furqon dengan mengajak semua murid (yang rumahnya dekat dengan sekolah) dan para dewan guru. Kami membersihkan ruang kelas dan mencabuti rumput liar yang tumbuh rimbun di halaman MA Al Furqon. Semua yang ikut dalam kerja bakti sangat antusias membersihkan lingkungan sekolah. Karena selama pandemic Covid-19, sekolah jarang dibersihkan. Sehingga ketika melihat sekolah sudah bersih dan rapi, pihak sekolah pun ikut senang.

\section{Memberikan Cinderamata dan Alat Kebersihan untuk Kenang-Kenangan}

Di hari yang sama setelah kerja bakti, kami memberikan cinderamata dan alat kebersihan kepada sekolah MA Al Furqon sebagai bentuk terimakasih tim KKN atas kerjasamanya dalam memperlancar kegiatan KKN kami. 


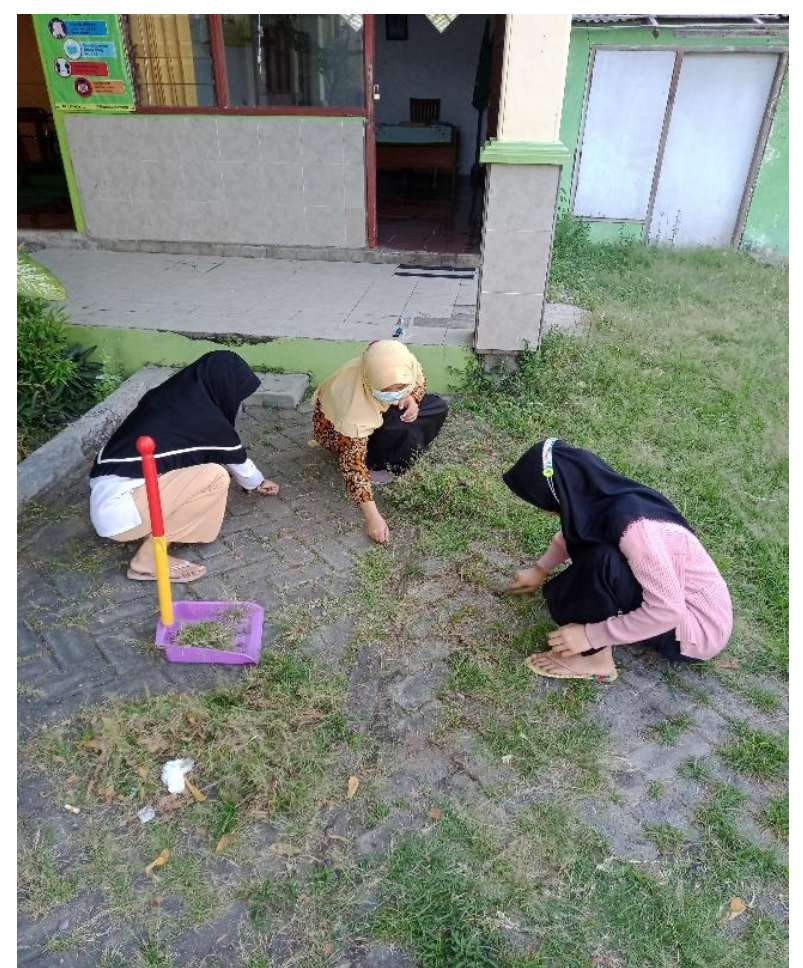

Gambar 5. Kerja Bakti Lingkungan Sekolah

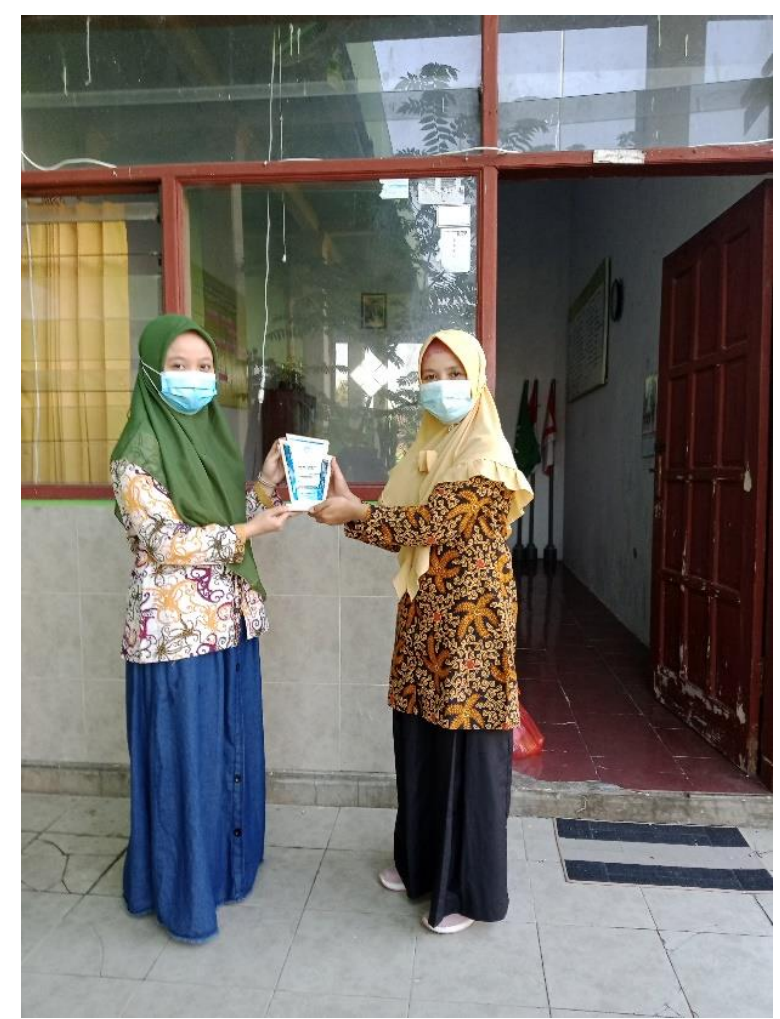

Gambar 6. Memberikan cinderamta 


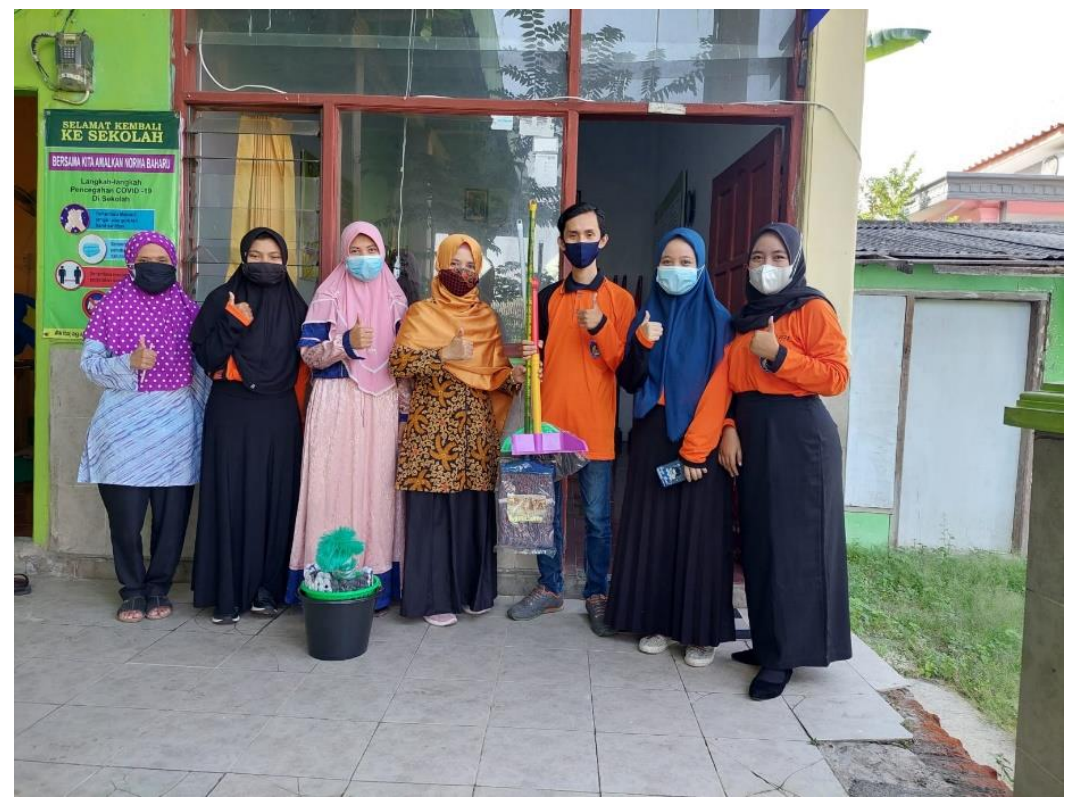

Gambar 7. Memberikan alat kebersihan

Selama sosialisasi berlangsung, terdapat tanya jawab seputar materi sosialisasi antara tim KKN dengan siswa kelas XII MA Al Furqon Pasuruan :

Siswa

Tim KKN

Siswa

Tim KKN

Siswa

Tim KKN

: Apakah hanya dengan SKTM bisa langsung mendapatkan KIP?

: Pihak kelurahan akan memeriksa kelayakan siswa penerima KIP yaitu berasal dari keluarga yang mampu ataukah tidak mampu. Biasanya ada catatannya di data BDT (Base Data Terpadu), jika layak maka akan langsung diajukan ke dinas sosial

: Apakah dengan kuliah, kita bisa sukses?

: Kesuksesan seseorang tergantung pribadi orang itu sendiri, niat apa tidak dalam menekuni pekerjaannya. Tetapi dengan kuliah, seseorang memiliki pengetahuan dan ketrampilan yang lebih matang untuk terjun ke dunia kerja dibandingkan dengan orang yang tidak kuliah. Karena di perkuliahan ada yang namanya magang, PPL, dan KKN yang tujuannya yaitu agar mahasiswa mampu beradaptasi dengan dunia kerja dan memiliki keahlian yang mumpuni sesuai dengan pekerjaan yang diambil.

: Kalau kuliah di Uniwara, nanti kerjanya jadi guru. Tetapi saya tidak mau jadi guru. Bagaimana dengan hal itu?

: Memang benar karena program studinya "Pendidikan" maka kebanyakan jadi guru. Tetapi banyak juga kok memiliki pekerjaan di luar guru, ada yang bekerja di Badan Pusat Statistik, ada yang bekerja sebagai teller di Bank, ada yang bekerja sebagai tenaga administrasi di rumah sakit, bisa juga menjadi Tour Guide jika jurusannya Prodi Bahasa Inggris dan Bahasa Indonesia, dan masih banyak lagi. Karena selain ijazah S-1 yang dibutuhkan di dunia kerja, tetapi juga kemampuan kalian sesuai pekerjaan yang dipilih.

Dengan adanya sosialisasi di MA Al Furqon Pasuruan, diharapkan dapat memotivasi peserta didik untuk melanjutkan pendidikan ke perguruan tinggi.

\section{KESIMPULAN}

Dengan terlaksanakanya semua program kerja KKN-DR Universitas PGRI Wiranegara Pasuruan di MA Al Furqon Pasuruan dengan kegiatan sosialisasi KIP Kuliah, sosialisasi pentingnya pendidikan tinggi untuk masa depan, sosialisasi program kemendikbud untuk mahasiswa, dan mengenalkan kampus uniwara mendapat respon positif dan sambutan yang baik dari pihak sekolah khususnya siswa kelas XII dan para dewan guru. Dengan kegiatan 
sosialisasi KIP diharapkan siswa dan dewan guru memahami betapa pentingnya mengurus KIP (bagi yang kurang mampu) untuk menunjang pendidikan, dengan demikian siswa bisa melanjutkan pendidikan sampai pendidikan tinggi tanpa takut biaya mahal. Begitupula dengan kegiatan sosialisasi pentingnya pendidikan tinggi untuk masa depan diharapkan siswa dapat melanjutkan pendidikan ke perguruan tinggi negeri maupun swasta untuk bekal masa depan. Dengan mengenyam pendidikan tinggi, seseorang memiliki pengetahuan dan ketrampilan yang matang untuk bisa terjun ke dunia kerja. Sedangkan sosialisasi program Kemendikbud untuk mahasiswa, agar siswa termotivasi untuk melanjutkan ke pendidikan tinggi dengan manfaatmanfaat yang akan diterima. Dan yang terakhir yaitu mengenalkan kampus Uniwara yang dekat dengan rumah, kuliah disana bisa juga disambi kerja. Kuliah pagi dan kerja sore, kebanyakan mahasiswa di Uniwara menerapkan hal itu. Jadi tidak ada alasan lagi untuk tidak kuliah di Uniwara karena ada banyak manfaat yang bisa diambil.

\section{DAFTAR PUSTAKA}

[1] A. A. Amilia, P. Ans'harikhu, M. A. A. Bimantara, L. Suciani, A. Yanuar, and P. Rahmawati, "Gerakan Ayo Kuliah Program Keluarga Harapan untuk Memotivasi Siswa Melanjutkan Pendidikan ke Perguruan Tinggi," Community Empower., vol. 5, no. 3, pp. 177-185, Dec. 2020, doi: 10.31603/ce.3986.

[2] K. H. Hajron et al., “Gerakan 'Ayo Kuliah' untuk anggota 'Program Keluarga Harapan' menuju perguruan tinggi," p. 8.

[3] Y. Mujiwati and M. Paramitha, "MENUMBUHKAN RASA KEPEDULIAN SISWA TERHADAP KEBERSIHAN LINGKUNGAN DI SEKOLAH MA AL MASYHUR BUGUL KIDUL KOTA PASURUAN," no. 2, p. 8, 2020.

[4] N. Hasanah, K. P. Rajagukguk, F. Syafitri, and T. Pujahadi, "Sosialisasi Tentang Pentingnya Pendidikan Tingkat Perguruan Tinggi Kepada Masyarakat Desa Jaring Halus," p. 7.

[5] K. H. Hajron, M. N. Zunnurain, W. Wahyuni, H. N. Afifah, B. D. Suprihanto, and A. Wulandari, "Gerakan Ayo Kuliah Bagi Anak KPM PKH di Kecamatan Muntilan untuk Meningkatkan Minat Sekolah Lanjutan," Community Empower., vol. 6, no. 3, pp. 384-390, Mar. 2021, doi: 10.31603/ce.3956. 